\title{
SINERGISITAS STAKEHOLDER DALAM PENGEMBANGAN DESA WISATA PUJON KIDUL KABUPATEN MALANG
}

\author{
Ika Rizkyah Khomzi*, Setiyo Yuli Handono*, Anis Trianawati**
}

\begin{abstract}
ABSTRAK
Penelitian ini bertujuan untuk mendeskripsikan sinergisitas stakeholder dalam pengembangan Desa Wisata Pujon Kidul dan dampak yang ditimbulkan dari adanya sinergisistas stakeholder. Penelitian ini menggunakan pendekatan kualitatif dan analisis data penelitian menggunakan model interaktif dari Miles dan Huberman. Penentuan informan kunci menggunakan purposive sampling dengan pertimbangan perwakilan dari masing-masing stakeholder yang terlibat dalam pengembangan Desa Wisata Pujon Kidul. Sinergisitas stakeholder dalam pengembangan Desa Wisata Pujon Kidul khususnya Cafe Sawah berada pada level respectful. Faktor pendukung dalam sinergisitas ini yaitu keterbukaan, saling menguntungkan, komunikasi yang baik, dan tidak adanya kepentingan pribadi. Faktor penghambat dalam sinergisitas ini yaitu persepsi masyarakat yang masih belum sama, komunikasi dengan BNI masih kurang, pengetahuan regulasi pemerintah yang kurang, dan mindset yang berorientasi pada uang. Dampak yang dirasakan masyarakat dari adanya sinergisitas ini yaitu penyerapan tenaga kerja, peningkatan lapangan kerja, peningkatan pendapatan, perubahan kesadaran masyarakat terhadap kebersihan, berkurangnya kenakalan remaja, budaya lokal mulai luntur, lingkungan semakin bersih, lalu lintas yang terganggu, dan alih fungsi lahan.
\end{abstract}

Kata kunci: sinergisitas; stakeholder; desa wisata.

\begin{abstract}
This study aimed to describe the synergy of stakeholders in development of Pujon Kidul village tourism and the impact from the synergy of stakeholder. This study used qualitative approach and the analysis data used interactif model from Miles and Huberman. Determination of informants was using purposive sampling with consideration of representatives from each stakeholders involved in the development of Pujon Kidul village tourism. The result showed that the level of synergy was in respectful level. The supporting factors in the synergy of stakeholders were openness, mutual benefits, good communications, and no personal interest. Inhibiting factors in the synergy of stakeholders were community perception about Cafe Sawah was different, lacking communication with BNI Brawijaya, lacking knowledge about regulation to develop Cafe Sawah, and mindset money oriented. The results also reveal the impact of the synergy of stakeholder in development Pujon Kidul village tourism especially in Cafe Sawah were employment, encouraging entrepreneurial activity, improve income, increased awareness about cleanliness, decreased of juvenile delinquency, local cultures began to disappear, increased cleanliness, disruptions of traffic around village, and agricultural land conversions.
\end{abstract}

Keywords: synergy; stakeholder; village tourism.

\section{PENDAHULUAN}

Sinergi menjadi hal yang penting dalam sebuah kegiatan yang dikerjakan secara bersama-sama. Hal tersebut dikarenakan sinergi dalam suatu kerja sama dimana antara satu pihak dengan pihak lainnya harus saling mendukung dan berkoordinasi untuk mewujudkan suatu kegiatan yang efisien (Hayati, 2014). Selain koordinasi yang mengharuskan adanya 
komunikasi, sinergi juga memerlukan faktor kepercayaan sebagai pendukungnya (Baru, Rusbiyanti, \& Harianto, 2018). Salah satu kegiatan yang membutuhkan sinergi yaitu pengembangan desa wisata. Berbagai stakeholder yang terlibat diharuskan untuk saling mendukung dan berkoordinasi guna untuk mewujudkan tujuan meningkatkan ekonomi masyarakat desa. Sektor pariwisata saat ini menjadi salah satu sektor yang mampu menyumbang pemasukan bagi desa yang mengembangkan potensi wisatanya. Prospek pengembangan agrowisata muncul sangat cepat di sektor entrepreneurship sebagai salah satu cara berwirausaha di sektor pertanian (Paresishvili, Kvaratskhelia, \& Mirzaeva, 2017). Menurut Lago (2017) menghubungkan pariwisata dengan pertanian mampu memberikan kesempatan bagi penguatan ekonomi lokal melalui produk lokal sebagai salah satu cara dalam meningkatkan industri pariwisata.

Salah satu desa wisata yang cukup terkenal di Kabupaten Malang yaitu Desa Pujon Kidul yang sedang berbenah membangun desanya menjadi kawasan desa wisata dengan destinasi utamanya yaitu Cafe Sawah. Jumlah wisatawan yang datang ke Cafe Sawah hingga akhir Oktober 2017 sebanyak 331.408 wisatawan (Kumalasari, Gutama, \& Pratiwi, 2018). Hal tersebut menunjukkan bahwa eksistensi Cafe Sawah yang cukup terkenal untuk tren wisata alam saat ini.

Pembangunan Desa Wisata Pujon Kidul tentunya tidak lepas dari stakeholder yang mendukungnya. Salah satu stakeholder yang terlibat dalam pengembangan desa wisata ini yaitu pemerintah desa yang membangun Badan Usaha Milik Desa (BUMDes) untuk mengembangkan potensi desa Pujon Kidul melalui sektor pariwisata. Selain itu, terdapat pihak dari perbankan yang menjadi penyalur CSR. Berdasarkan penelitian yang dilakukan Prabowo, S.E., Hamid, Djamhur, \& Prasetya, (2016) masyarakat Pujon Kidul masih kurang berpastisipasi aktif dalam pengembangan desa wisata dikarenakan terkendala oleh kurangnya motivasi masyarakat, sosialisasi, sumber daya manusia rendah, dan kesulitan masyarakat dalam mengurus perizinan terkait produk olahan makanan khas. Pernyataan tersebut juga didukung oleh Agfianto, Antara, \& Suardana (2019) yang menyatakan bahwa kebebasan partisipasi masyarakat harusnya terjadi dalam pengelolaan sebuah destinasi wisata, namun pengelolaan Cafe Sawah seluruhnya diserahkan kepada Pokdarwis (Kelompok Sadar Wisata) dan masyarakat hanya diberi ruang usaha pendirian kios disekitar destinasi wisata, sedangkan bagi masyarakat yang tidak melakukan usaha dan tidak ada aktivitas di destinasi tersebut tidak mendapat dampak meskipun mayarakat tersebut merupakan penduduk lokal Pujon Kidul.

Hal tersebut tidak sesuai dengan pernyataan Dewi, Fandeli, \& Baiquni (2013) bahwa masyarakat lokal berperan penting dalam pengembangan desa wisata karena sumber daya dan keunikan tradisi serta budaya yang melekat pada komunitas tersebut merupakan unsur penggerak utama kegiatan di desa wisata. Pernyataan tersebut juga didukung oleh Wearing \& Mcdonald (2002) yang menyatakan bahwa masyarakat lokal berkedudukan sama penting dengan pemerintah dan swasta sebagai salah satu stakeholder dalam pengembangan pariwisata. Maka, sangat diperlukan keterlibatan masyarakat dalam pengembangan desa wisata agar sesuai dengan kebutuhan masyarakat serta masyarakat mampu mendapatkan manfaat dari pengembangan desa wisata tersebut.

Penelitian mengenai peran dan partisipasi stakeholder dalam mengembangkan suatu desa sudah banyak dilakukan. Beberapa diantaranya yaitu penelitian yang dilakukan oleh Prabowo, S.E., Hamid, Djamhur dan Prasetya (2016) yang menjelaskan mengenai partisipasi masyarakat dalam pengembangan Desa Wisata Pujon Kidul namun belum menjelaskan partisipasi stakeholder lain dalam pengembangan desa wisata Pujon Kidul. Penelitian yang dilakukan oleh 
Mahfud, Haryono, \& Anggraeni (2014) yang menjelaskan mengenai peran dan koordinasi yang dilakukan oleh stakeholder dalam pengembangan kawasan Minapolitan di Kabupaten Blitar namun belum menjelaskan kondisi kesinergisan antar stakeholder yang terlibat dalam kegiatan tersebut.

Keberhasilan Desa Wisata Pujon Kidul tentunya tidak lepas dari sinergi yang terjalin antar stakeholder. Melihat permasalahan yang terjadi di Desa Pujon Kidul mengenai kurangnya partisipasi masyarakat dalam pengembangan Desa Wisata Pujon Kidul maka penting dilakukan penelitian mengenai Sinergisitas Stakeholder dalam Pengembangan Desa Wisata Pujon Kidul, Kecamatan Pujon, Kabupaten Malang. Penelitian ini diharapkan dapat memperoleh informasi mengenai sinergisitas antar stakeholder dalam pengembangan Desa Wisata Pujon Kidul.

Berdasarkan uraian tersebut, penelitian ini memiliki tujuan sebagai berikut :

1. Mendeskripsikan sinergisitas stakeholder dalam pengembangan Desa Wisata Pujon Kidul.

2. Mendeskripsikan dampak sinergisitas stakeholder dalam pengembangan Desa Wisata Pujon Kidul dari segi ekonomi, sosial dan lingkungan.

\section{METODE PENELITIAN}

$\begin{array}{lcr}\text { Penelitian } & \text { ini } & \text { menggunakan } \\ \text { pendekatan } & \text { kualitatif. } & \text { Penelitian }\end{array}$
dilaksanakan di Cafe Sawah, Desa Wisata Pujon Kidul, Kecamatan Pujon, Kabupaten Malang pada bulan Januari hingga Februari 2019. Informan kunci yang digunakan untuk meneliti sinergisitas stakeholder sebanyak 5 orang yang terdiri dari perwakilan pemerintah Desa Pujon Kidul, BNI Brawijaya, BUMDes Sumber Sejahtera, dan Pengelola Cafe Sawah. Sedangkan informan yang digunakan untuk meneliti dampak yang dirasakan oleh masyarakat sebanyak 10 orang yang terdiri dari BUMDes Sumber Sejahtera, Pokdarwis, Pengelola Cafe Sawah, pemilik wahana, pekerja, pedagang, dan petani. Teknik penentuan informan menggunakan pendekatan non-probability sampling dengan metode purposive sampling.

Teknik pengumpulan data melalui indepth interview, observasi, dan dokumentasi. Peneliti dalam melakukan indepth interview menggunakan pedoman wawancara yang sudah disusun dan dialog yang terjadi selama kegiatan tersebut berlangsung. Observasi dilakukan oleh peneliti dengan cara melakukan pengamatan terhadap kegiatan wisata di Cafe Sawah, Desa Pujon Kidul yang melibatkan pemerintah desa, BNI Brawijaya dan masyarakat. Dokumentasi dilakukan oleh peneliti dengan mengumpulkan data pada arsip, laporan, gambar, foto, dan lain sebagainya yang didapatkan dari pemerintah desa dan masyarakat.

Analisis data dalam penelitian ini menggunakan model interaktif untuk mendeskripsikan data atau hasil catatan lapang secara kualitatif. Model interaktif dari Miles dan Huberman terdiri dari pengumpulan data, kondensasi data, penyajian data, dan verifikasi data. Keabsahan data diuji dengan menggunakan triangulasi teknik. Triangulasi teknik digunakan oleh peneliti dengan cara mengecek data kepada sumber yang sama dengan teknik yang berbeda saat pengambilan data. Data awal yang diperoleh oleh peneliti melalui wawancara kemudian dicek kembali melalui data yang didapatkan dengan teknik observasi dan dokumentasi. Hasil yang diperoleh dari ketiga teknik tersebut kemudian dibandingkan untuk menghasilkan data yang valid dan kredibel.

\section{Hasil dan Pembahasan Sinergitas Stakeholder}

\section{a. Kepercayaan}

Pemerintah desa dan masyarakat yang terdiri dari BUMDes Sumber Sejahtera dan pengelola Cafe Sawah saling mengetahui tugas masing-masing dalam pengembangan Cafe Sawah. Pemerintah Desa Pujon Kidul, BUMDes Sumber Sejahtera dan pengelola Cafe Sawah hanya mengetahui BNI 
Brawijaya sebagai penyuplai dana melalui CSR.

Kepercayaan antar stakeholder didasari dengan pengetahuan mengenai tugas dan tanggung jawab masing-masing stakeholder. Kepercayaan yang dimaksud merupakan keyakinan individu atau para aktor stakeholder yang terlibat dalam pengembangan desa wisata terhadap diri sendiri dan aktor lain untuk dapat menjalankan peran dan tanggungjawabnya (Fairuza, 2017). Menurut Leman (2018) kepercayaan antar stakeholder dapat terbentuk karena adanya hubungan antar aktor yang bekerjasama menjadi saling bergantung terhadap tugas dan perannya masing-masing. Sehingga perlu untuk saling mengetahui tugas dari masing-masing stakeholder yang terlibat.

Kepercayaan antara pemerintah desa, BNI Brawijaya, dan masyarakat yang terdiri dari BUMDes Sumber Sejahtera dan pengelola Cafe Sawah tercipta dikarenakan adanya transparansi yang dilakukan oleh ketiga stakeholder tersebut. Pemerintah desa melakukan transparansi kepada BNI Brawijaya melalui pelaporan terkait transaksi yang dilakukan dari dana CSR yang diberikan. Transparansi anggaran dana oleh pemerintah desa kepada masyarakat luas dilakukan setiap 1 tahun sekali, transparansi capaian dan perencanaan dengan BUMDes Sumber Sejahtera dan pengelola Cafe Sawah dilakukan minimal setiap 3 bulan sekali pada periode 2018, untuk periode 2019 direncanakan untuk melakukan pertemuan setiap 1 bulan sekali.

Transparansi menjadi salah satu alasan kepercayaan masyarakat pada pemerintah atas kinerja yang telah dilakukan dalam pengembangan Cafe Sawah. Kepercayaan sosial dalam masyarakat akan mendorong masyarakat itu sendiri pada sebuah kolaborasi sosial untuk kepentingan bersama, sehingga kepercayaan timbal balik penting adanya terutama antara pemerintah dan masyarakat melalui penyediaan informasi dan menjamin kemudahan dalam memperoleh informasi yang akurat dan memadai (Bakti et al., 2018; Ningrum, 2016).

\section{b. Komunikasi}

Komunikasi yang terjalin antar pemerintah desa dan masyarakat yang terdiri dari BUMDes Sumber Sejahtera dan pengelola Cafe Sawah sudah efektif. Hal tersebut dibuktikan dengan kemudahan dalam berkomunikasi, baik komunikasi langsung maupun komunikasi tidak langsung. Komunikasi langsung terjadi saat pertemuan rutin antara pemerintah desa, BUMDes Sumber Sejahtera dan pengelola Cafe Sawah setiap 3 bulan sekali. Komunikasi tidak langsung juga memiliki intensitas yang tinggi, melalui grup percakapan online selalu mendapatkan informasi terkait wisata khususnya Cafe Sawah setiap hari.

Komunikasi yang dilakukan oleh seluruh stakeholder baik melalui pertemuan langsung maupun alat perantara berupa handphone sebagai alat pendukung komunikasi menandakan komunikasi yang dijalin sudah efektif. Menurut Nurjanah dan Yasir (2014) komunikasi interpersonal yang terbentuk melalui pertemuan-pertemuan merupakan salah satu sarana komunikasi yang efektif dalam penyebaran informasi inovasi kepada masyarakat. Penggunaan media sosial dalam pengembangan destinasi wisata dalam berkomunikasi satu dengan lainnya juga dirasa cukup efektif, efisien, terjangkau, dan mudah dalam mengoperasionalkannya (Bakti et al., 2018).

Komunikasi yang terjalin antara BNI Brawijaya dengan stakeholder lain jarang dikarenakan kesibukan dari masing-masing stakeholder dan komunikasi terjadi disesuaikan dengan keperluan. Salah satu contoh kegiatannya yaitu pengembangan kapasitas sumberdaya melalui bimbingan teknis untuk kepengurusan BUMDes. Hal tersebut dapat terjadi karena menurut Saepudin, Budiono, dan Rohman (2016) bahwa dalam proses komunikasi, komunikator dan komunikan dituntut untuk mempunyai kepentingan yang sama, karena tanpa hal tersebut komunikasi tidak akan 
berlangsung dengan semestinya. Hal tersebut menjelaskan bahwa komunikasi pemerintah desa, BUMDes Sumber Sejahtera dan pengelola Cafe Sawah dengan BNI Brawijaya saat ini bukan pembahasan khusus untuk mengembangkan Cafe Sawah.

Seluruh stakeholder memberikan respon yang cepat kepada stakeholder lain saat melakukan komunikasi. Pemberian respon yang cepat membuktikan bahwa komunikasi yang terjalin antar seluruh stakeholder berjalan dengan baik. Responsifitas atau daya tangkap dari pemerintah merupakan kemampuan untuk mengidentifikasi kebutuhan masyarakat, sehingga pemerintah harus tanggap dengan apa yang diharapkan dan yang dibutuhkan oleh masyarakat dalam suatu program yang sedang dijalankan (Ningrum, 2016).

Pemberian laporan sebagai salah satu cara transparansi kepada seluruh stakeholder merupakan kegiatan yang penting. Hal tersebut menunjukkan bahwa adanya umpan balik dari satu pihak ke pihak lainnya. Sedarmayanti (2004) menyatakan bahwa transparansi merupakan salah satu prinsip Good Governance yang dibangun dalam rangka kebebasan aliran informasi. Kepemerintahan yang baik akan bersifat transparan terhadap rakyatnya, baik ditingkat pusat maupun daerah (Ningrum, 2016; Sedarmayanti, 2004).

Praktik komunikasi yang terjadi dalam pengembangan Desa Wisata Pujon Kidul khususnya Cafe Sawah juga masih memperoleh hambatan berupa kesalahpahaman yang terjadi di antara stakeholder terkait. Sehingga, kembali harus dilakukan komunikasi ulang melalui musyawarah agar permasalahan dan kesalahpahaman yang terjadi tidak semakin menjadi masalah yang besar.

\section{c. Kreativitas}

Kreativitas yang dijalin antara pemerintah desa, BNI Brawijaya, BUMDes Sumber Sejahtera dan pengelola Cafe Sawah dilihat dari kemampuan menciptakan ide. Pemerintah desa, BNI Brawijaya dan BUMDes Sumber Sejahtera tidak memberikan ide pengembangan untuk Cafe Sawah. Keseluruhan ide pengembangan berasal dari pengelola Cafe Sawah yang nantinya usulan ide ini akan diberitahukan pada pemerintah desa dan BUMDes Sumber Sejahtera pada saat pertemuan rutin guna untuk mendapatkan persetujuan dari pemerintah desa.

Resiko terbesar yang pernah dilakukan dalam pengembangan Cafe Sawah yaitu pada saat pembangunan Cafe Sawah itu sendiri. Hal tersebut dikarenakan pembangunan Cafe Sawah yang mulanya hanya untuk memberdayakan masyarakat sekitar Desa Pujon Kidul khususnya pengangguran belum dapat diprediksi akan berhasil di kemudian hari. Hingga saat ini, belum ada lagi resiko besar yang diambil oleh berbagai stakeholder untuk mengembangkan Cafe Sawah. Namun, dalam waktu dekat akan dilakukan pembangunan yang cukup beresiko dikarenakan membutuhkan dana yang cukup besar.

Kreativitas dalam pengembangan Cafe Sawah dianggap belum mencapai taraf keberhasilan. Cafe Sawah dirasa masih belum berhasil dikarenakan belum meratanya dampak yang dirasakan oleh masyarakat, belum adanya pergantian pengurus dan pengelola selama Cafe Sawah ini berdiri dan kepuasan manusia yang selalu meningkat, sehingga dari hasil yang ada saat ini dirasa masih belum puas. Namun, jika dilihat dari penghasilan dari Cafe Sawah sendiri yang sudah mencapai 2 miliar rupiah dalam kurun waktu kurang lebih 2 tahun, hal ini merupakan suatu prestasi yang luar biasa.

Keberhasilan suatu pengembangan desa wisata dapat dilihat berdasarkan komunikasi yang terjadi, jika komunikasi terjalin dengan baik dan terdapat interaksi sosial yang positif dalam pengembangan wisata alam, maka akan mendukung pula keberhasilan pengembangan tersebut (Ningrum, 2016). Selain itu, salah satu faktor keberhasilan suatu program pengembangan lainnya yaitu peran stakeholder yang harus mampu menciptakan komunikasi dan hubungan yang baik sehingga dapat 
menyalurkan aspirasi masyarakat pelaku wisata (Putri \& Manaf, 2013). Berdasarkan penjelasan tersebut, maka dapat disimpulkan kegiatan pengembangan Cafe Sawah ini sudah berhasil dilihat dari komunikasinya, hanya saja terdapat beberapa hal yang masih harus diperbaiki untuk meningkatkan manfaatnya di masyarakat.

Secara keseluruhan, berdasarkan 3 aspek sinergisitas yang sudah dijelaskan di atas, maka sinergi yang terjalin antara pemerintah desa, BNI Brawijaya dan masyarakat yang terdiri dari BUMDes Sumber Sejahtera dan pengelola Cafe Sawah merupakan sinergi yang respectful. Menurut Covey (1997) sinergi yang respectful menandakan bahwa antar stakeholder memilki respek satu sama lain tetapi ingin menghindari kemungkinan konfrontasi yang tidak menyenangkan, sehingga seluruh stakeholder yang terlibat berkomunikasi dengan sopan, tetapi tidak dengan empati. Komunikasi yang penuh respek memang baik dalam situasi yang bebas atau mandiri, tetapi kemungkinan kreatifnya belum terbuka. Dalam situasi yang saling tergantung, kompromi adalah posisi yang biasa diambil. Kompromi berarti seluruh stakeholder samasama memberi dan menerima.

\section{Kegiatan} maupun proses pengembangan suatu wilayah yang berbasis pada potensi lokal, selalu memiliki suatu dukungan dan hambatan tertentu. Sinergi dalam pengembangan Cafe Sawah yang dilakukan oleh pemerintah desa, BNI Brawijaya, BUMDes Sumber Sejahtera dan pengelola Cafe Sawah memiliki berbagai faktor yang mendukung dan menghambat jalannya kerja sama tersebut. Faktor pendukung ini didapatkan berdasarkan hasil wawancara peneliti dengan 5 orang informan kunci. Berikut merupakan faktor yang mendukung terjalinnya sinergi antar stakeholder terkait dalam pengembangan Cafe Sawah.

\section{Keterbukaan}

Keterbukaan yang dimaksud yaitu segala sesuatu baik perencanaan, pelaksanaan, dan hasil kegiatan harus dijelaskan pada masing- masing stakeholder. Keterbukaan akan mengurangi kecurigaan dari masing-masing stakeholder karena seluruh kegiatan tidak ada yang ditutupi, terutama untuk hal yang beresiko tinggi seperti keuangan. Secara tidak langsung, keterbukaan mampu meningkatkan kepercayaan antar stakeholder. Adanya pertanggungjawaban dari setiap kegiatan yang dilakukan juga mampu meningkatkan kepercayaan antar stakeholder.

\section{Saling Menguntungkan}

Salah satu keberhasilan sebuah kerja sama yaitu memiliki hasil dari kegiatan yang selama ini telah diusahakan. Kerja sama harus saling menguntungkan satu sama lain. Walaupun, dalam kegiatan pengembangan Cafe Sawah, BNI Brawijaya tidak menerima keuntungan secara langsung karena memberikan dana CSR, namun pihak BNI mendapatkan nasabah dari Desa Pujon Kidul dengan kerja samanya bersama BUMDes Sumber Sejahtera di unit Laku Pandai (Simpan Pinjam).

\section{Komunikasi}

Untuk mendapatkan informasi terkait segala kegiatan yang ada di bagian wisata Desa Pujon Kidul, seluruh stakeholder mengandalkan komunikasi sebagai cara terbaik. Melalui komunikasi, masing-masing stakeholder mampu mengatasi ketimpangan informasi dan mengatasi permasalahan yang terjadi. Komunikasi yang dimaksudkan merupakan komunikasi langsung dan komunikasi tidak langsung. Saat ini tidak dapat dipungkiri bahwa manusia sangat membutuhkan alat bantu komunikasi berupa handphone atau gawai. Gawai ini dianggap sangat membantu komunikasi antar stakeholder terkait menjadi lebih praktis. Memudahkan dalam pemantauan kegiatan dan juga dalam memberikan arahan tertentu dalam kegiatan pengembangan Cafe Sawah.

\section{Tidak Ada Kepentingan Pribadi}

Pengembangan Cafe Sawah melibatkan banyak pihak diantaranya pemerintah desa, BNI Brawijaya, BUMDes Sumber Sejahtera dan pengelola Cafe Sawah. Kerja sama yang baik merupakan kerja sama yang tidak 
mengutamakan kepentingan pribadi, melainkan demi kepentingan kelompok. Dalam kegiatan pengembangan Cafe Sawah, yang sangat diharapkan merupakan peningkatan ekonomi dan kesejahteraan masyarakat Desa Pujon Kidul dari adanya Cafe Sawah tersebut dan mampu menjadi desa wisata yang mandiri. Hal ini yang harus diutamakan oleh setiap pihak guna mewujudkan keinginan yang diharapkan.

Faktor penghambat merupakan faktorfaktor yang dianggap memberikan gangguan terhadap pelaksanaan pengembangan Cafe Sawah oleh stakeholder terkait. Faktor penghambat ini didapatkan berdasarkan hasil wawancara peneliti dengan 5 orang informan kunci. Berikut merupakan faktor yang menghambat terjalinnya sinergi antar stakeholder terkait dalam pengembangan Cafe Sawah.

\section{Persepsi}

Saat ini, masih banyak masyarakat secara luas yang masih belum memahami tujuan keberadaan Cafe Sawah. Beberapa masyarakat masih memiliki pro dan kontra mengenai keberadaan Cafe Sawah dikarenakan beberapa dari masyarakat merasa belum mendapatkan manfaat dari adanya Cafe Sawah. Sehingga, masih harus disamakan persepsi yang ada di masyarakat, untuk mendukung kerja sama ini. Hal tersebut, dikarenakan masyarakat merupakan target utama dalam pengembangan Cafe Sawah guna untuk meningkatkan kesejahteraan masyarakat itu sendiri.

\section{Komunikasi dengan BNI yang Kurang}

Komunikasi mampu menjadi faktor pendukung dan penghambat apabila peran komunikasi tidak dimaksimalkan dalam melakukan kerjasama untuk pengembangan Cafe Sawah ini. Komunikasi antara pihak pengelola Cafe Sawah, BUMDes Sumber Sejahtera, dan pemerintah desa dengan pihak BNI Brawijaya masih belum optimal. Hal ini dapat terjadi dikarenakan terdapat beberapa pihak yang mampu melaksanakan komunikasi dengan baik sedangkan terdapat pihak lain yang masih kurang. Namun, kerja sama ini tetap berjalan dengan saling menutupi kekurangan masing-masing.

\section{Pengetahuan tentang Regulasi Kurang}

Regulasi dalam pemerintah berfungsi sebagai peraturan dalam melaksanakan suatu kegiatan yang bersentuhan langsung dengan pemerintah. Sehingga kebutuhan akan regulasi sangat penting. Bagi beberapa pihak, regulasi pemerintah yang bersifat kaku menjadi hal yang dapat menghambat jalannya kerja sama. Beberapa orang masih awam terhadap regulasi pemerintahan yang ada khususnya untuk melakukan pengambangan Cafe Sawah. Hal ini yang menyebabkan anggapan regulasi pemerintahan menjadi penghambat dalam jalannya kerja sama untuk pembangunan Cafe Sawah.

\section{Mindset Pengelola}

Salah satu penghambat dari kerja sama yang terjalin untuk pengembangan Cafe Sawah adalah mindset atau pola pikir pengelola yang masih berorientasi pada uang. Hal tersebut terjadi dikarenakan kondisi Cafe Sawah yang saat ini menjadi salah satu sumber Pendapatan Asli Desa (PAD) yang cukup besar jumlahnya. Sehingga orientasi seluruhnya mulai ke arah keuntungan yang sebesar-besarnya. Padahal, tujuan utama dari dikembangkannya Cafe Sawah ini yaitu untuk meningkatkan kesejahteraan masyarakat melalui potensi lokal.

\section{Dampak dari Sinergitas Stakeholder}

\section{a. Dampak Ekonomi}

Dampak ekonomi yang ditimbulkan dari adanya pengembangan Cafe Sawah yaitu dengan banyaknya pembukaan lapangan pekerjaan, maka meningkat pula penyerapan tenaga kerja. Maka, secara tidak langsung menurunkan tingkat pengangguran dan juga meningkatkan pendapatan masyarakat. Hal tersebut sesuai dengan Agfianto, Antara, \& Suardana (2019) yang menyatakan bahwa pendapatan masyarakat meningkat akibat adanya pengeluaran dari pengunjung yang datang ke Pujon Kidul untuk mengunjungi wisata Cafe Sawah. Adanya pengembangan desa wisata mampu membuka lapangan 
pekerjaan di bidang pertanian lebih banyak, sehingga penyerapan tenaga kerja meningkat dan pengangguran menurun (Bhandari, 2013; Lupi, Giaccio, Mastronardi, Giannelli, \& Scardera, 2017). Pengembangan desa wisata juga akan memperbanyak sumber pendapatan masyarakat, sehingga akan terjadi peningkatan kesejahteraan masyarakat khususnya petani. Pariwisata dapat membantu meningkatkan taraf kehidupan masyarakat melalui aspek finansial (Iorio dan Corsale, 2010).

b. Dampak Sosial

Dampak sosial yang ditimbulkan dari adanya pengembangan Cafe Sawah diawali dari kesadaran masyarakat yang menganggap bahwa kebersihan sebagai salah satu atraksi wisata sangat diperlukan. Hal tersebut sesuai dengan pernyataan Hijriati dan Mardiana (2014) setelah adanya pengembangan ekowisata, terjadi perubahan perilaku dengan semakin sadarnya masyarakat terhadap kebersihan lingkungan karena semakin banyaknya wisatawan, semakin banyak pula sampah yang ada, sehingga mulailah masyarakat untuk melakukan pengelolaan terhadap sampah yang ada. Dampak sosial positif lainnya yaitu penurunan kenakalan remaja, dikarena remaja yang pengangguran diberdayakan melalui Cafe Sawah. Namun, dibalik itu juga terdapat dampak negatif yaitu budaya lokal Desa Pujon Kidul mulai luntur di kalangan remaja. Kenakalan remaja tidak hanya menjadi tanggung jawab bagi orang tua namun juga milik masyarakat sebagai tanggung jawab moral kehidupan, sehingga penurunan kenakalan remaja juga diperlukan (Rahmah, 2017). Perubahan perilaku remaja yang terjadi di lokasi wisata dipengaruhi oleh budaya yang dibawa oleh pengunjung, sehingga dengan mudah para remaja meniru cara berpakaian dan cara bergaul dengan sebaya menggunakan budaya baru tersebut (Rahmah, 2017).

\section{c. Dampak Lingkungan}

Dampak lingkungan yang ditimbulkan dari adanya pengembangan Cafe Sawah yaitu kebersihan lingkungan yang terjaga. Lingkungan yang bersih mejadi salah satu pendukung atraksi wisata di Desa Pujon Kidul. Selain itu, kegiatan wisatawan cukup membuat kondisi lalu lintas di Desa Pujon Kidul terganggu, salah satunya yaitu karena kemacetan, sehingga dilakukan pengaturan lalu lintas keluar masuk kendaraan menuju dan keluar Cafe Sawah Menurut Purmada, Wilopo, dan Hakim (2016) dampak adanya kegiatan kerja bakti terhadap kelestarian lingkungan hidup adalah terjaganya kelestarian dan kerapian lingkungan karena dalam kegiatan kerja bakti dilaksanakan beberapa kegiatan pengaturan lingkungan. Masyarakat memiliki kesadaran untuk mengelola kawasan wisata yang dulunya hanya kampung menjadi kawasan ekowisata yang akan sering dikunjungi keluar dan masuk kampung tersebut (Hijriati \& Mardiana, 2014).

Kegiatan alih fungsi guna lahan pertanian menjadi non-pertanian tidak menutup kemungkinan digunakan untuk kawasan wisata. Meskipun kegiatan pertanian tersebut berbasis pertanian, namun pada kenyataannya perkembangan pariwisata menyebabkan banyaknya alih fungsi guna lahan pertanian. Adanya kegiatan wisata memunculkan harapan bagi masyarakat untuk mendapatkan keuntungan sebesarbesarnya melalui penyediaan layanan wisata, sehingga banyak dilakukan alih fungsi lahan pertanian yang berdampak terhadap tata guna lahan pertanian yang terancam eksistensinya dikarenakan pembangungan wisata yang dibangun diatas lahan persawahan (Dipayana \& Sunarta, 2015)

\section{KESIMPULAN}

Berdasarkan penelitian yang dilakukan pada stakeholder dalam pengembangan Cafe Sawah di Desa Wisata Pujon Kidul, Kecamatan Pujon, Kabupaten Malang, dapat ditarik beberapa kesimpulan, diantaranya adalah sebagai berikut :

1. Berdasarkan 3 aspek dalam sinergi yaitu kepercayaan, komunikasi dan kreativitas, sinergisitas stakeholder dalam pengembangan Cafe Sawah di Desa Pujon Kidul, Kecamatan Pujon, 
Kabupaten Malang memiliki tingkatan sinergi respectful.

2. Dampak sinergisitas stakeholder dalam pengembangan Desa Wisata Pujon Kidul berdasarkan aspek ekonomi yaitu adanya penyerapan tenaga kerja, peningkatan jumlah lapangan kerja, dan peningkatan pendapatan masyarakat. Dampak sosial dari adanya sinergisitas stakeholder dalam pengembangan Cafe Sawah di Desa Pujon Kidul, Kecamatan Pujon, Kabupaten Malang yaitu perubahan kesadaran masyarakat terhadap kebersihan, berkurangnya kenakalan remaja dan budaya lokal yang mulai luntur. Dampak lingkungan dari adanya sinergisitas stakeholder dalam pengembangan Cafe Sawah di Desa Pujon Kidul, Kecamatan Pujon, Kabupaten Malang yaitu lingkungan yang bersih, lalu lintas terganggu dan alih fungsi lahan pertanian.

Berdasarkan kesimpulan yang telah diuraikan, maka dapat dikemukakan beberapa saran yang bersifat membangun bagi beberapa stakeholder yang terlibat dalam pengembangan Cafe Sawah di Desa Pujon Kidul, Kecamatan Pujon, Kabupaten Malang, diantaranya sebagai berikut :

1. Pemerintah Desa Pujon Kidul dan BNI Brawijaya sebaiknya meningkatkan partisipasi pemberian ide dalam pengembangan Cafe Sawah

2. BNI Brawijaya sebaiknya meningkatkan komunikasi dengan pihak pemerintah desa dan masyarakat diluar pembahasan mengenai perbankan, sehingga nantinya jika terdapat dana CSR yang akan dikeluarkan lagi, mampu mencapai sasaran yang sesuai yang dibutuhkan oleh Desa Pujon Kidul dalam rangka peningkatan kualitas Cafe Sawah kedepannya.

\section{DAFTAR PUSTAKA}

Agfianto, T., Antara, M., \& Suardana, I. W. (2019). Dampak Ekonomi Pengembangan Community Based Tourism Terhadap Masyarakat Lokal di Kabupaten Malang (Studi Kasus
Destinasi Wisata Cafe Sawah Pujon Kidul). Jurnal Master Pariwisata, 05(02), 259-282.

Bakti, I., Sumartias, S., Damayanti, T., \& Nugraha, R. (2018). Pengembangan Model Komunikasi Pariwisata Berbasis Kearifan Lokal di Kawasan Geopark Pangandaran. Jurnal Kajian Komunikasi, 6(2), 217-230.

Baru, B., Rusbiyanti, S., \& Harianto, H. (2018). Sinergitas Fungsi Modal Sosial (Social Capital) dan Fungsi Pemerintahan Desa. Seminar Nasional Sistem Informasi (SENASIF) (Vol. 2).

Bhandari, P. B. (2013). Rural Livelihood Change? Household Capital, Community Resources and Livelihood Transition. Journal of Rural Studies, 32, 126-136.

https://doi.org/10.1016/j.jrurstud.2013.0 5.001

Covey, S. R. (1997). 7 Kebiasaan Manusia yang Sangat Efektif. Jakarta: Binarupa Aksara.

Dewi, M. H., Fandeli, C., \& Baiquni, M. (2013). Pengembangan Desa Wisata Berbasis Partisipasi Masyarakat Lokal di Desa Wisata Jatiluwih Tabanan, Bali. Jurnal Kawistara, 3(2), 129-139. https://doi.org/10.22146/kawistara.3976

Dipayana, A., \& Sunarta, I. N. (2015). Dampak Pariwisata Terhadap Alih Fungsi Lahan di Desa Tibubeneng Kecamatan Kuta Utara Kabupaten Badung (Studi Sosial-Budaya). Jurnal Destinasi Pariwisata, 3(2), 58-66.

Fairuza, M. (2017). Kolaborasi antar Stakeholder dalam Pembangunan Inklusif pada Sektor Pariwisata (Studi Kasus Wisata Pulau Merah di Kabupaten Banyuwangi). Jurnal Kebijakan Dan Manajemen Publik, 5(3), 1-13.

Hayati, N. (2014). Sinergi LembagaLembaga Pemerintahan/BUMN dalam Penyaluran Bantuan Program Keluarga Harapan (PKH) di Kota Samarinda. 
Jurnal Ilmu Pemerintahan, 2(4), 3482 3496.

Hijriati, E., \& Mardiana, R. (2014). Pengaruh Ekowisata Berbasis Masyarakat Terhadap Perubahan Kondisi Ekologi, Sosial, dan Ekonomi di Kampung Batusuhunan, Sukabumi. Jurnal Sosiologi Pedesaan, 02(03), 146-159.

Iorio, M., \& Corsale, A. (2010). Rural Tourism and Livelihood Strategies in Romania. Journal of Rural Studies, 26(2), 152-162. https://doi.org/10.1016/j.jrurstud.2009.1 0.006

Kumalasari, R. D., Gutama, W. A., \& Pratiwi, D. E. (2018). Analisis Pengaruh Electronic Word of Mouth ( eWOM ) Terhadap Keputusan Berkunjung ke Agrowisata Café Sawah Pujon Kidul The Effect of Electronic Word of Mouth ( eWOM ) on Willingness to Visit AgroTourism of Café Sawah Pujon Kidul. Jurnal Habitat, 29(2), 65-75. https://doi.org/10.21776/ub.habitat.2018 .029 .2 .8

Lago, N. A. A. (2017). Tourism Demand and Agriculture Supply: Basis for Agritourism Development in Quezon Province. Asia Pacific Journal of Multidisciplinary Research, 5(3), 1-9.

Leman, L. A. (2018). Kolaborasi antar Stakeholders dalam Pengembangan Pariwisata Religi Sunan Giri di Kabupaten Gresik. Jurnal Kebijakan Dan Manajemen Publik, 6(2), 1-11.

Lupi, C., Giaccio, V., Mastronardi, L., Giannelli, A., \& Scardera, A. (2017). Exploring the Features of Agritourism and Its Contribution to Rural Development in Italy. Journal of Land Use Policy, 64, 383-390. https://doi.org/10.1016/j.landusepol.201 7.03.002

Mahfud, M. A., Haryono, B., \& Anggraeni, N. (2014). Peran dan Koordinasi Stakeholder dalam Pengembangan Kawasan Minapolitan di Kecamatan
Nglegok, Kabupaten Blitar. Jurnal Administrasi Publik, 3(12), 2070-2076.

Ningrum, E. A. (2016). Studi Penerapan Good Governancen dalam Pegelolaan Desa Wisata Kampung Bandar Kecamatan Senapelan Kota Pekan Baru Tahun 2012-2014. Jurnal Online Mahasiswa Fisip, 3(2), 1-15.

Nurjanah, \& Yasir. (2014). Strategi Komunikasi Inovasi dalam Pengembangan Potensi Desa Wisata. Jurnal Ilmu Komunikasi, 5(1), 61-72.

Paresishvili, O., Kvaratskhelia, L., \& Mirzaeva, V. (2017). Rural Tourism as a Promising Trend of Small Business in Georgia: Topicality, Capabilities, Peculiarities. Journal of Annals of Agrarian Science, 15(3), 344-348. https://doi.org/10.1016/j.aasci.2017.07.0 08

Prabowo, S.E., Hamid, Djamhur, Prasetya, A. (2016). Analisis Partisipasi Masyarakat dalam Pengembangan Desa Wisata ( Studi Pada Desa Pujonkidul Kecamatan Pujon Kabupaten Malang ). Jurnal Administrasi Bisnis, 33(2), 1824.

Purmada, D. K., Wilopo, \& Hakim, L. (2016). Pengelolaan Desa Wisata dalam Perspektif Community Based Tourism (Studi Kasus pada Desa Wisata Gubugklakah, Kecamatan Poncokusumo, Kabupaten Malang). Jurnal Administrasi Bisnis, 32(2), 1522.

Putri, H. P., \& Manaf, A. (2013). Faktor Faktor Keberhasilan Pengembangan Desa Wisata di Dataran Dieng. Jurnal Teknik PWK, 2(3), 559-568.

Rahmah, W. (2017). Dampak Sosial Ekonomi dan Budaya Objek Wisata Sungai Hijau Terhadap Masyarakat di Desa Salo Kecamatan Salo Kabupaten Kampar. Jurnal Online Mahasiswa Fisip, 4(1), 1-16.

Saepudin, E., Budiono, A., \& Rohman, A. S. (2016). Strategi Komunikasi dalam 
Pengembangan Desa Wisata Agro di Kabupaten Bandung Barat. Jurnal Edulib, 6(2), 154-168. Retrieved from https://dx.doi.org/10.17509/edulib.v6i2. 5027.g3575

Sedarmayanti. (2004). Good Governance (Kepemerintahan yang Baik). Bandung: Mandar Maju.

Wearing, S., \& Mcdonald, M. (2002). The
Development of Community-based Tourism: Re-thinking the Relationship Between Tour Operators and Development Agents as Intermediaries in Rural and Isolated Area Communities. Journal of Sustainable Tourism, 10(3), 191-208. https://doi.org/0966-9582

1

*Dosen Jurusan Sosial Ekonomi, Fakultas Pertanian, Universitas Brawijaya ***Dosen di Universitas Tribhuwana Tunggadewi

(*Email: ikarizkyah@gmail.com) 